\title{
Comparative Study in Habitat Suitability Analysis of Wild Water Buffalo (Bubalus arnee) in Two Flood Plains of Chitwan National Park (CNP), Nepal
}

\author{
Kripa Pokhrel ${ }^{1}$, Prabin Poudel ${ }^{2 *}$, Bijaya Neupane ${ }^{3}$, Rabin Paudel ${ }^{4}$ \\ ${ }^{I}$ Ministry of Industry, Tourism, Forest and Environment, Gandaki Province, Pokhara, Nepal \\ ${ }^{2}$ Green Governance Nepal, Kathmandu Nepal \\ ${ }^{3}$ Tribhuvan University, Institute of Forestry, Pokhara, Nepal \\ ${ }^{4}$ National Trust for Nature Conservation, Annapurna Conservation Area Project, Pokhara, Nepal
}

*Corresponding Author: Prabin Poudel, Green Governance Nepal, Kathmandu, Nepal

\begin{abstract}
Globally endangered species, Wild Water Buffaloes are restricted to some extent of South and Southeast Asia. Its only population in Nepal survive on the flood plains of Koshi River inside Koshi Tappu Wildlife Reserve (KTWR). They prefer alluvial grasslands and are heavily dependent on water. In KTWR, they face high anthropogenic pressure ranging from habitat deterioration to hybridization with domestic buffaloes. Hence, 15 of them have been translocated to CNP which are to be released in the wild soon from the open closure. However, the suitability analysis of potential habitat within CNP has not been done until now. Consequently, this research is carried out to find the appropriate habitat of water buffalo within Chitwan National Park for their release as well as for further translocation. Two potential habitats namely eastern sector grassland and western sector grassland were identified, analyzed and compared to determine the habitat suitability for wild water buffalo. Vegetation composition, slope, elevation, proximity to the water source and human settlement were the parameters that were selected to assess the suitability. The results showed that Saccharum arundinaceum was the dominant tall grass species in the both sites (IVI in eastern grassland=105.34, IVI of western grassland=102.49) followed by Saccharum spontenum and Imperata cylindrical. Similarly, Bombax ceiba was the dominant tree species (IVI=12.57) followed by Trewia nudiflora and others in eastern sector whilst Syzigium cumini was the dominant tree species (IVI=68.11) followed by Bombax ceiba and Trewia nudiflora in western sector. The integration of all factors has shown that both sites possess suitable habitat for water buffalo but comparatively western sector (65.74\%) was more preferrable than the eastern sector (52.77\%). Accordingly, western sector grassland can be considered as the new worthy site for further translocation of wild water buffalo in CNP.
\end{abstract}

Keywords: Translocation, Habitat Suitability. Geospatial. Open Enclosure

Abbreviations: CNP-Chitwan National Park, ACAP-Annapurna Conservation Area Project, KTWR-KoshiTappu Wildlife Reserve, IVI-Important Value Index, IUCN-International Union for Conservation of Nature, CITES-Convention on International Trade in Endangered Species, GPS-Global Positioning System, LULCLand Use Land Cover, RD-Relative Density, RC-Relative Cover, GIS-Geographical Information System, DNPWC-Department of National Park and Wildlife Conservation, NTNC-National Trust for Nature Conservation.

\section{INTRODUCTION}

Wild Wild Water Buffaloes (Bubalus arnee) are the second largest members of the family Bovidae under the order Artiodactyla. They weigh between 800-1200 kg, and are a massive, powerful animal with the widest horn span of any bovid i.e. more than $2 \mathrm{~m}$ [1]. Their home range size ranges from 1.7 sq. $\mathrm{km}$ to $10 \mathrm{sq} . \mathrm{km} \mathrm{[15]} \mathrm{and} \mathrm{the} \mathrm{gestation} \mathrm{period} \mathrm{is} \mathrm{of} \mathrm{about} \mathrm{300-340} \mathrm{days} \mathrm{and} \mathrm{give} \mathrm{birth} \mathrm{to} \mathrm{a} \mathrm{single}$ calf at a time. The maximum life span of $B$. arnee is 25 years in the wild [15]. They are highly social animals and females remain in the groups in which they are born. Adult males live either as resident bulls in mixed herds comprised of females and their dependent off-spring, or as bachelors, either singly or in herds [8]. All population of B. arnee are considered to be endangered to critically-endangered for many reasons [9] and have probably been in decline for at least a century [7, 4]. They are listed as 'Endangered' on the IUCN Red List of Threatened Species since 1986, and appear under Appendix III 
of CITES, also, legally protected in Nepal, India, Bhutan and Thailand. The global population of $B$. arnee has been estimated at 3,400 individuals of which 91\% live in India, mostly Assam [5]. B. arnee's main diet is grasses and leafy aquatic vegetation so they prefer low lying alluvial grasslands and their surroundings. They are heavily dependent on water and spend much considerable time wallowing in rivers or mud holes and are more frequently encountered in riverine forests and grasslands, marshes and swamps. They are chiefly grazer, feeding in the morning and evening and lying up in dense cover or wallowing in mid-day heat, to keep themselves cool, and to remove skin parasites, biting flies, and other pests. They are sometimes completely submerged while wallowing, with only showing the nostrils and where there is a substantial human disturbance, they mainly adapt being nocturnal. The important factors determining the choice of habitat for $B$. arnee appears to be food and water rather than protection against predators and environmental factors like heat stress [4].

In Nepal, Koshi Tappu Wildlife Reserve (KWTR) is the only habitat that supports the last surviving population of 441 Wild water buffaloes (KTWR, 2018), until some of them were translocated to Chitwan National Park (CNP) in January 2017. B. arnee of KTWR are seriously threatened [10] and the most serious existing threats are interbreeding with feral and domestic buffaloes, followed by hunting, poaching, habitat loss/degradation, diseases and parasites and inter-specific competition for food and water [12]. In addition, the entire reserve is prone to flooding during monsoon as it lies within the embankments of the Koshi River [19], which apparently results in high calf mortality when the flood is underway [6, 8]. This single isolated population within the country has no possibility of immigration and emigration, hence, there is a strong need to shift some of the population into other suitable habitats for establishing sub-populations.

Additionally, CNP is considered as one of the most likely habitats for translocation of $B$. arnee: it possesses several required factors like better protection, qualitative habitat, extensive riverine habitat adjacent to upland forests for flood refuge [10]. B. arnee were known to occur in Chitwan until the 1960's [18]. Keeping this in mind, 15 B. arnee have already been translocated to CNP but some of them were died and suffering from the parasitic diseases and even Tiger attacked [20] and [21]. However, the habitat suitability analysis of CNP specifically for $B$. arnee has not been done till now. Hence, this study is an attempt to use geospatial solutions, satellite data and field data along with vegetation survey in the field for the analysis of habitat suitability of two different potential sites and determine the better site as the habitat of $B$. arnee which is supposed to aid further translocation and release of translocated buffaloes in suitable area within CNP.

\section{MATERIALS AND METHODS}

\subsection{Locations}

The study was conducted in Chitwan National Park, which is the first National Park, established in 1973 and enlisted in the world heritage site in 1984. It is situated in the southern part of Central Nepal The study was conducted in Chitwan National Park (CNP), which is the first National Park of Nepal, established in 1973 and enlisted in the UNESCO world heritage site in 1984 [22]. The CNP is situated in the southern part of Central Nepal, in the Subtropical low lands of the inner terai of Chitwan, Makwanpur, Parsa and Nawalparasi district lying in between $27.282-27.703{ }^{\circ} \mathrm{N} \& 83.839-84.773{ }^{\circ} \mathrm{E}$ surrounded by an additional 750 sq.Km. buffer [23] and the park covers an area of 952.63 sq. k.m., and about $70 \%$ of the area is covered by Sal forest [2]. Three major rivers; Narayani, Rapti and Reu and their flood plains and several other lakes and pools are the major water sources of this park. A total of 68 species of mammals, 54 species of birds, 56 species of herpetofauna and 126 species of fish have been recorded. The park is particularly famous for endangered fauna like One-horned rhinoceros (Rhinoceros unicornis), Gaur (Bos Gauras), Royal Bengal Tiger (Panthera tigris), Wild elephant (Elephus maximus) and many more [24]. Two large patches of floodplains i.e. eastern sector grassland and western sector grassland were selected as our study site for further analysis after consultation with the Park authorities as they are the most potential site for translocation of wild water buffalo. The eastern sector grassland falls under the Suaraha sector of CNP adjacent to Rapti River while the western sector grassland falls under Meghauli sector and Kasara sector of CNP adjacent to Rapti River and Reu River. These two grasslands are the important grasslands of CNP for the wild water buffaloes. 


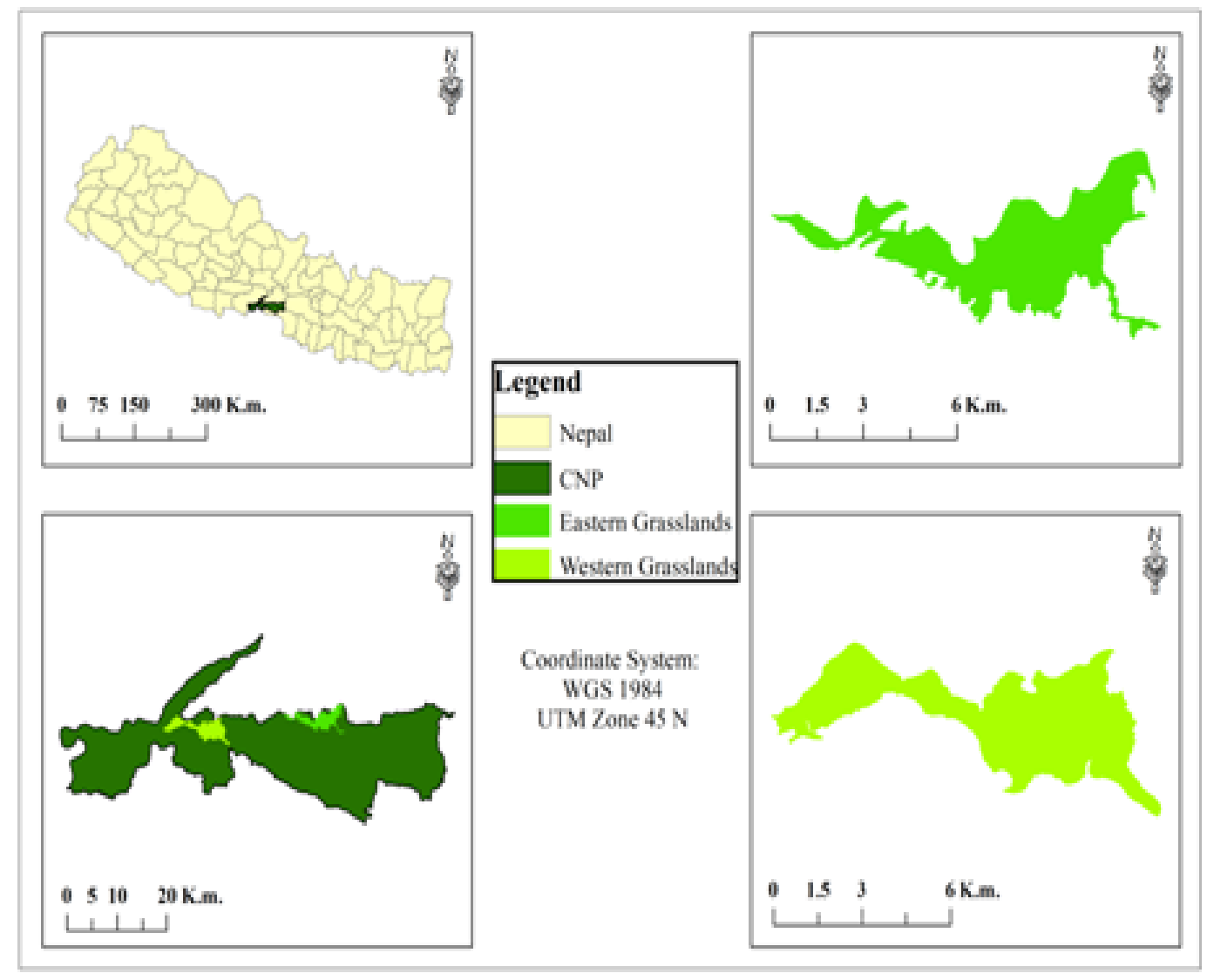

Figure1. Study Area

\subsection{Data Collection}

Two patches of floodplain (the study sites), the eastern and western grasslands, were digitized by using Google Earth Pro 7.3.2.5776 and $1 \mathrm{~km} \times 1 \mathrm{~km}$ grids were overlaid through fishnet tool in ArcGIS 10.5 and systematic sample plots were laid on both study areas. The coordinates of center points of grids were extracted and uploaded in GPS. During the field survey, each grid was navigated and three sample plots in each grid; one at the center and two other plots $250 \mathrm{~m}$ away on either side of the center point were surveyed for the vegetation analysis. The quadrate size of $25 \mathrm{~m} \times 20 \mathrm{~m}$ was taken for trees, $10 \mathrm{~m} \times 10 \mathrm{~m}$ for poles and $1 \mathrm{~m} \times 1 \mathrm{~m}$ was taken for grasses. Species composition, frequency and coverage of grasses along with GPS coordinates were recorded from each plot.

\subsection{Habitat Suitability Analysis}

Potential sites for the habitat of $B$. arnee were found out based on the preferred suitable habitat criteria. Suitability criteria of $B$. arnee were prepared by reviewing available literature, consultations and discussions with wildlife experts and officials of KTWR including holders. Various criteria were listed and the potential range of threshold values was set from less preferred to highly preferred. Habitat suitability criteria of $B$. arnee was classified into different suitability categories based on resource selection functions of the species and sensitivity to the physical attributes and human activities. The determining factors of habitat suitability were vegetation type/land use, distance from the water source, distance from settlement, slope and elevation [23]. With the use of Rapid Eye Image of 2011 for Land Use Land Cover (LULC) Mapping vegetation type/land use (Forest type/grassland type) were determined; vegetation analysis computed from the data collected from field; proximity to water sources/holes, settlement and slope were calculated using Aster DEM satellite Image and remaining two factors distance from water and the settlement was defined by using water and settlement thematic maps. Habitat values were assigned by putting the habitat quality ranking (HQR) using a common scale, so the criteria can be compared (Table 1). Regarding the common scale, it helps to produce worth values after combining all criteria together. At last, putting together gives the values from higher to lower level i.e. higher values resulting a map which represent the preferable habitat locations. 
Comparative Study in Habitat Suitability Analysis of Wild Water Buffalo (Bubalus arnee) in Two Flood Plains of Chitwan National Park (CNP), Nepal

Table1. Criteria for Habitat Suitability for wild water buffalo

\begin{tabular}{|l|l|l|l|l|}
\hline Habitat Suitability & $\begin{array}{l}\text { Vegetation/Land } \\
\text { Use Type }\end{array}$ & $\begin{array}{l}\text { Distance from } \\
\text { water/river (m) }\end{array}$ & $\begin{array}{l}\text { Distance from } \\
\text { Settlement (m) }\end{array}$ & $\begin{array}{l}\text { Slope } \\
\text { (Degree) }\end{array}$ \\
\hline Highly Suitable (4) & $\begin{array}{l}\text { River bed/ } \\
\text { Bushes/Shrubs }\end{array}$ & Within 500 & Greater than 2000 m & \\
\hline Suitable (3) & $\begin{array}{l}\text { Grassland/ } \\
\text { Waterbodies }\end{array}$ & 500 to 1000 & 1000 to 2000 & $<7^{\circ}$ \\
\hline Moderately Suitable (2) & Riverine Forest & 1000 to 2000 & 500 to 1000 & $>7^{\circ}$ \\
\hline Least Suitable (1) & Sal Forest & Greaterr than 2000 & Less than 500 & \\
\hline
\end{tabular}

\subsection{Vegetation Analysis}

The vegetation data collected from field was used to calculate species richness, density, relative density, frequency, and relative frequency of the trees and by using the following relation:

Density of species A = Total No. of individuals of species A / Total No. of areas surveyed x Area of plot

Relative density of species A = Total No. of individual of species A / Total number of individuals of all species

Frequency of species $A=($ Number of plots in which species $A$ occurs $x$ 100 $) /$ Total number of plot samples

Relative Frequency of species A = (Frequency value of species A x 100) / Total frequency value of all species

Relative dominance of species A = Total basal area of species A x 100) / Total basal area of all species

\subsection{Important Value index (IVI)}

For Grasses IVI= Relative Density (RD) + Relative Frequency (RF) + Relative Cover (RC)

For Trees IVI = Relative Density $(\mathrm{RD})+$ Relative Frequency $(\mathrm{RF})+$ Relative Basal Area

\subsection{Framework of GIS Analysis}

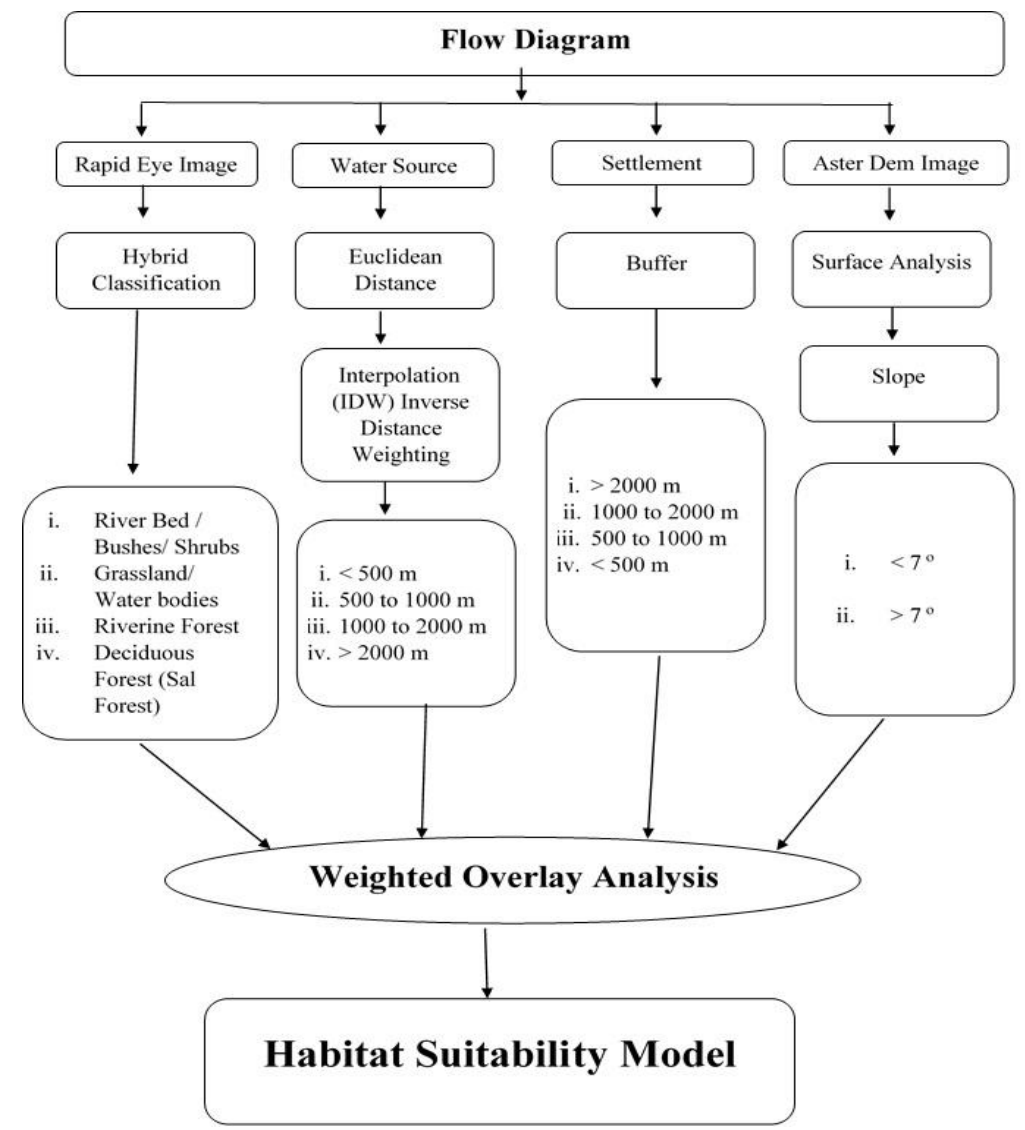

Figure2. Methodological Flow Diagram 


\section{ReSUlts}

\subsection{IVI of Grass Species}

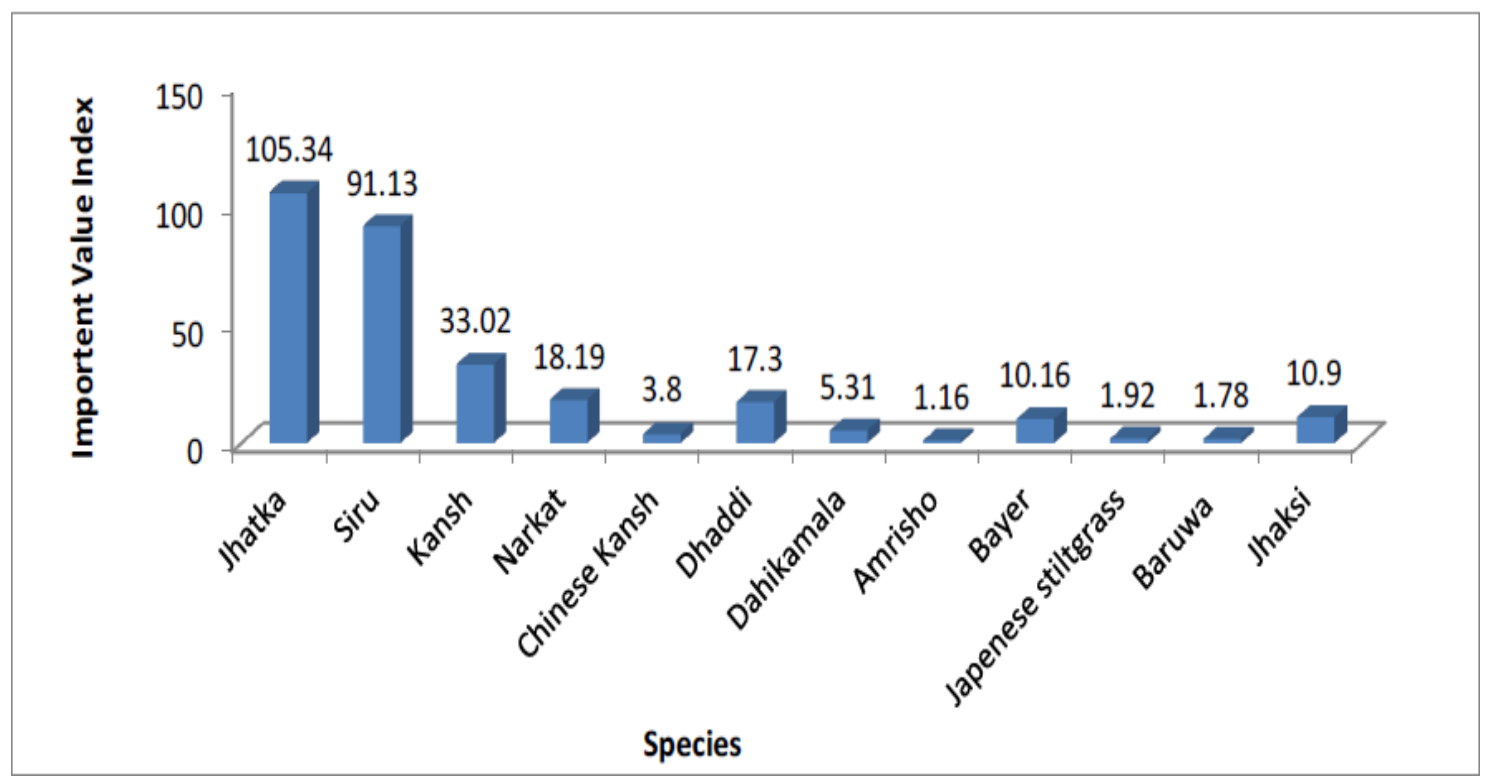

Figure3. IVI of Grass Species in Eastern Sector

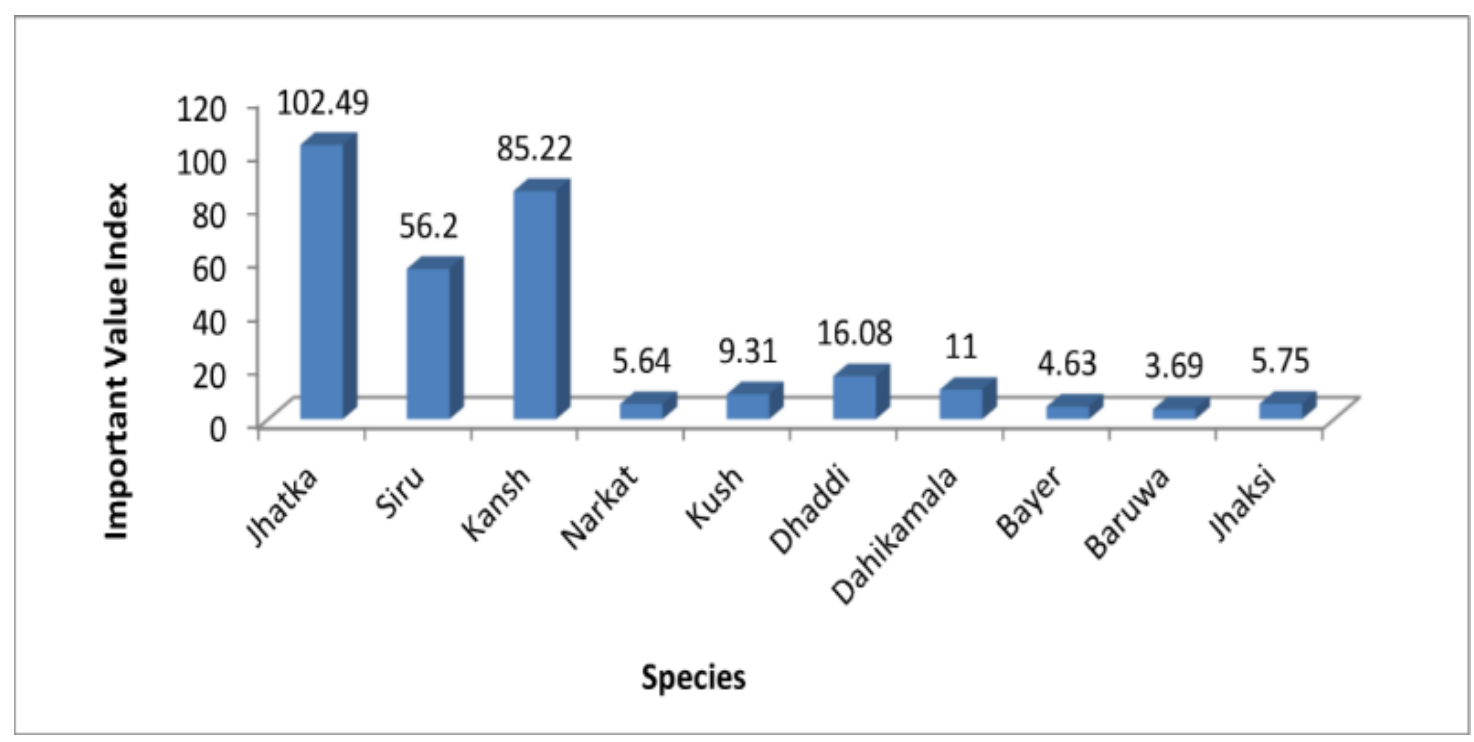

Figure4. IVI of Grass Species in Western Sector

All total 12 species of tall grasses were recorded out of which the dominant grass species recorded in the eastern sector grassland was Jhatka (Saccharun arundinacium) with IVI of 105.34 followed by Siru (Imperata cylindrical) with IVI of 91.13 and Kansh (Saccharum spontaenum) with IVI of 33.02 as the second and third most dominant species respectively. The Relative Density of Jhatka, Siru and Kansh were $17.24 \%, 60.39 \%$ and $10.89 \%$ respectively and the relative coverage were $59.30 \%, 17.94 \%$, and $7.73 \%$ respectively.

Likewise, in the western sector grassland consists of 10 different species of tall grasses. Out of which, dominant species was same Jhatka (Saccharun arundinacium) with IVI value of 102.49 followed by Kansh (Saccharum spontaenum) in this site with its IVI value of 85.22 and Siru (Imperata cylindrical) with IVI of 56.20 as the second and third most dominant species respectively. The relative density of Jhatka, Kansh and Siru were found to be $17.63 \%, 31.37 \%$ and $37.10 \%$ respectively and the relative coverage were found to be $48.35 \%, 32.98 \%$, and $8.66 \%$ respectively.

In addition, among the small species found in the eastern sector, Fern (Drypteris sps.) was found to be dominant with Relative coverage of $24.57 \%$ followed by Unyu with Relative coverage of $17.24 \%$ and 
Dicanthium annulatum with relative coverage of $9.48 \%$. Accompanying, there was presence of species like Cynodon dactylon and Cyperus dichtome in eastern sector grassland. Likewise, the small grasses of western grassland consists of Banso (Digitaria ciligara) as dominant one with the relative coverage of $38.47 \%$ followed by Niuro (Dryopteris cochleata) with relative coverage of $12.46 \%$ and Cynodon dactylon with relative coverage of $7.96 \%$. In addition to this, there was presence of Dichanthium annulatum and Kuro (Desmodiuml axiflorum)in the western sector grassland.

\subsection{IVI of Trees Species}

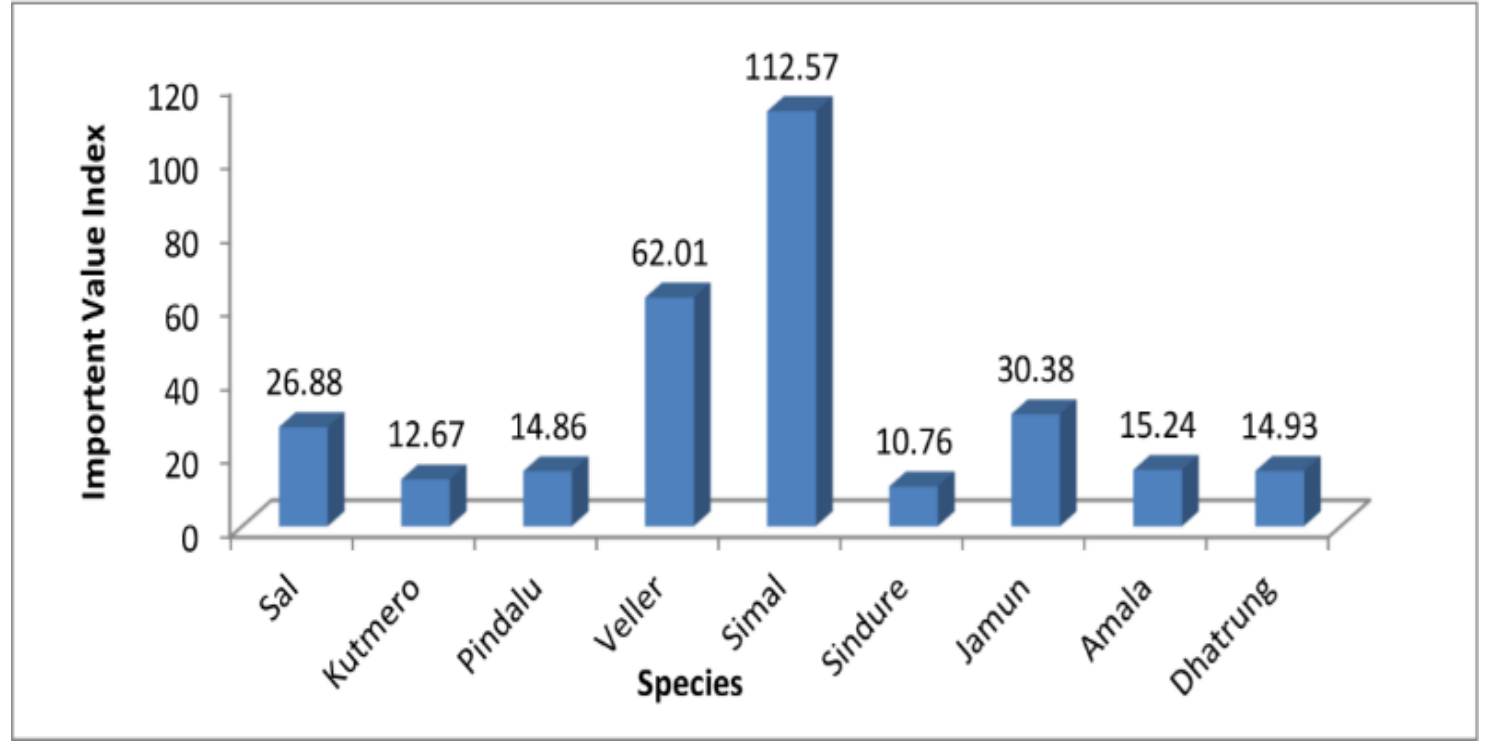

Figure5. IVI of Tree Species in Eastern Sector

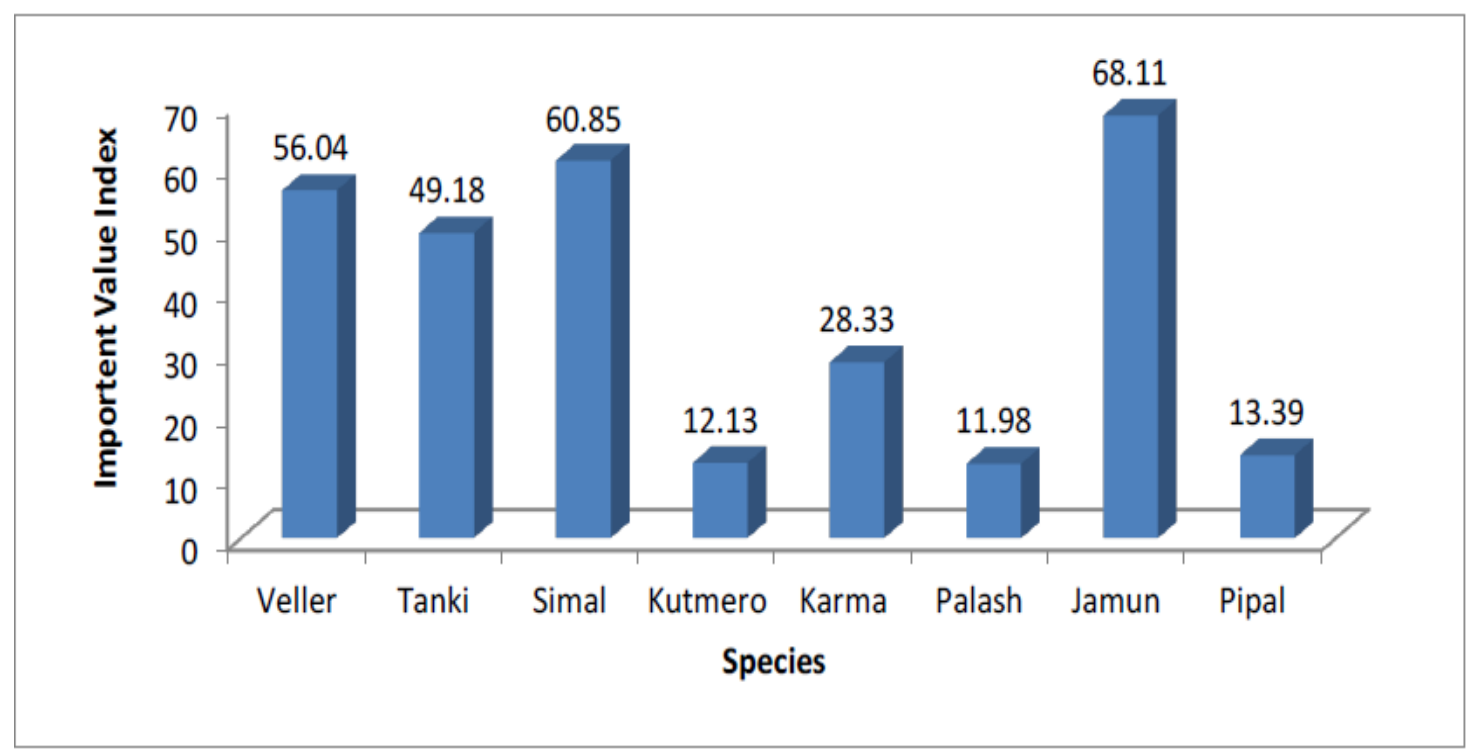

Figure6. IVI of Tree Species in Western Sector

In parallel to grass species, total of 9 species of trees were recorded in eastern sector grassland. The most dominant tree species was Simal (Bombax ceiba) with IVI of 112.57 and Relative Density and Relative Basal Area was $29.17 \%$, and $54.0 \%$ respectively. The second dominant species was Veller (Trewia nudiflora) with its IVI value 62.01 and Relative Density and Relative Basal Area as $29.16 \%$ and $15.19 \%$.

Likewise, the grassland of western sector consists of Jamun (Syzigium cumini) as dominant species with IVI value 68.11 which is followed by Simal (Bombax ceiba) with IVI value 60.84. The third dominant species was Veller (Trewia nudiflora) with IVI value 56.08 and the $4^{\text {th }}$ dominant species was Tanki (Baunia purpuria) with IVI value of 49.18. The relative density of Jamun, Simal, Veller and Tanki were $27.27 \%, 22.73 \%, 13.64 \%$ and $18.18 \%$ respectively. 


\subsection{Habitat Suitability}



Figure7. Habitat Suitability Map of Eastern Flood Plain

In total, eastern sector grassland covers 1943.88 ha out of which 1025.85 ha $(52.77 \%)$ was predicted as highly suitable habitat while 918.03 ha $(49.79 \%)$ was least suitable. In figure 7 and 8 the green color represents the highly suitable area while red color least suitable area.

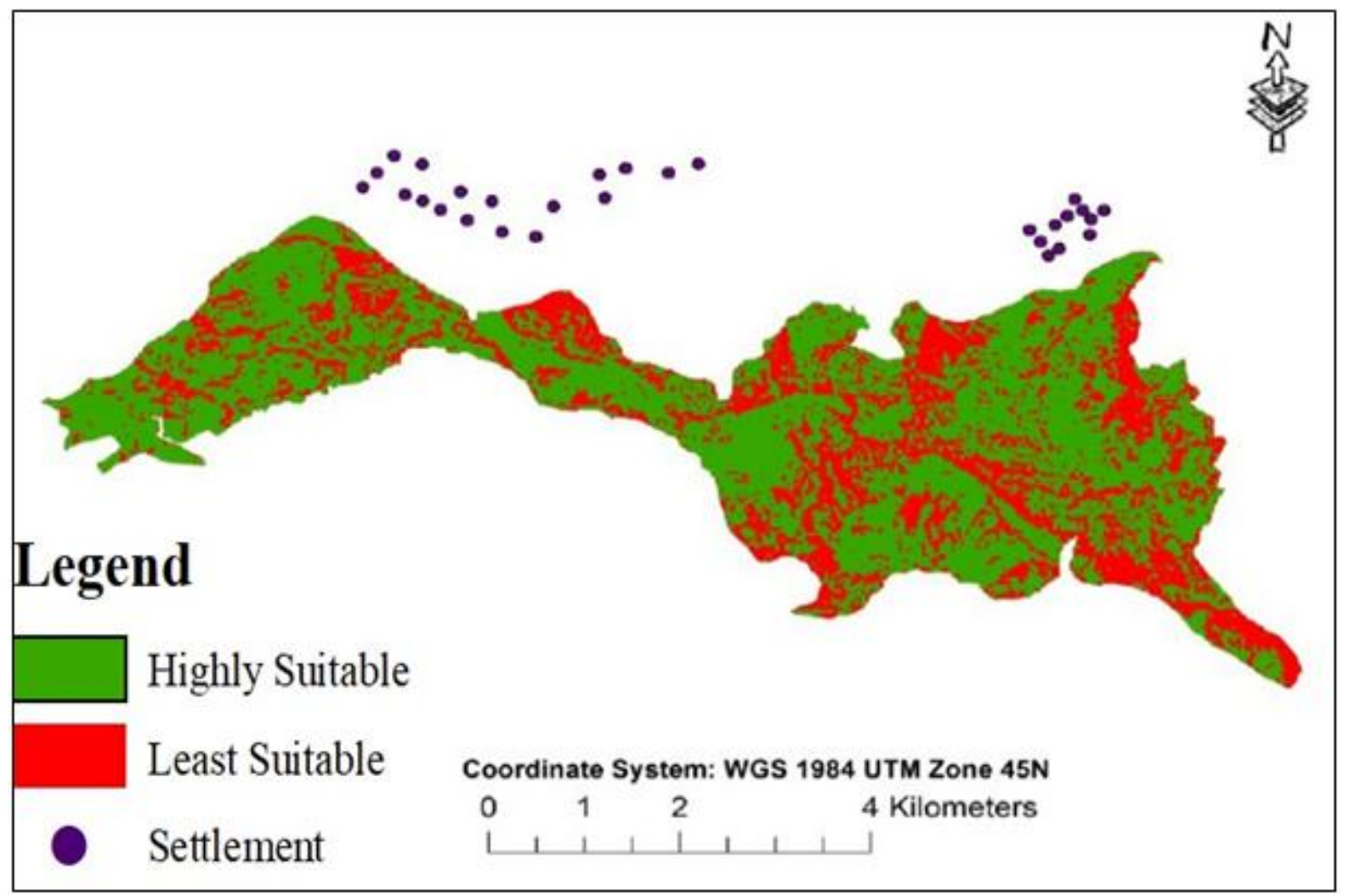

Figure8. Habitat Suitability Map of Western Flood Plain 
Similarly, in the western sector grassland, out of 2422.67 ha analyzed, the highly suitable area predicted for the habitat of water buffalo was found 1593.57 ha $(65.78 \%)$ and the least suitable area was 829.1 ha $(34 \%)$.

Comparing the habitat components of water buffalo in the study sites, the results showed that both eastern and western sector possess dominant vegetations preferred by $B$. arnee. The composition of tall grass in both sites was almost the same though the second dominant and third dominant species were Siru (I. cylindrical) and Kansh (S. spontenum) in the eastern sector and Kansh (S. spontenum) and Siru (I. cylindrical) in western sector. Despite of all, dominant species are the preferred food of water buffalo. Similarly, while comparing the small grasses composition, more small grasses preferred by $B$. arnee were found in the western sector than eastern sector grassland. At the same time, while comparing the tree species of two sites the dominance of deciduous species was more in eastern sector i.e. Simal (Bombax ceiba) and Veller (Trewia nudiflora) while in western sector result showed the presence of evergreen species i.e. Jamun (Syzygium cumini) as dominant species. Hence, we can say that both areas are suitable as habitat of water buffalo on the basis of vegetation analysis.

Similarly, while comparing the results of geospatial analysis both areas are suitable as the habitat of wild water buffalo on the basis of distance from the settlement, slope and elevation as a huge portion of study area possess slope below $7^{\circ}$, elevation less than $300 \mathrm{~m}$ and almost all area is far from settlement. While comparing the water body there is the presence of flowing water body in both study sites while more amount of water body is present in the western sector than the eastern sector. Hence, as water buffalo need more water and sand body as its habitat it can be concluded that western sector grassland is more suitable for water buffalo on the basis of geospatial analysis.

\section{DisCUSSIONS}

According to [13], both S. spontaneum and I. cylindrical are the most preferred species of B. arnee. Similarly, [2] have agreed on Arundo donax, Saccharum arundinaceum and S. spontaneum as the most preferred foods of $B$. arnee in Thailand. Thus, regarding the study areas both possesses the similar species preferred by $B$. arnee as a dominant species as shown by IVI, resulted the both of areas have suitable habitat based on the availability of preferred foods. In addition, the vegetation analysis also revealed that other grass species like Narket (Phragmite karka), Baruwa ( $S$. bengalensis), Dubo (Cynodon dactylon), Mother (Cyperus dichtome), Dichanthium annulatum and Kuro (Desmodium laxiflorum) were also present which are consumed by wild water buffalo [13]. Similarly, [14] has also agreed on the presence of these species in study area, which makes these areas more suitable for $B$. arnee. Additionally, the most preferred habitat of B. arnee consist of Bombax ceiba, Dalbergia sissoo and Acacia catechu [16]. In KTWR, the major forest type used by B. arnee is Acacia-Dalbergia forest [17]. The IVI index of trees in the study sites indicate the dominant species as Bombax ceiba followed by Trewia nudiflora and Sizygium cumini. Thus, the presence of the forest type preferred by B. arnee makes it more suitable for the translocation program.

The geo-spatial analysis of the study area shows that the studied sites are far from all kinds of human influences, hence there are numerous chances of interbreeding with domestic buffalo, but such problem is prevalent in KTWR. The elevation analysis of study sites shows that all area studied is below $330 \mathrm{~m}$, hence these criteria were not used for further analysis. According to [11], CNP consists of a mosaic of tall grasslands, short grasslands, riverine forests and Sal forest as well as plenty of wetlands and waterholes created by natural or artificial oxbow lakes and water flowing from Churia which is quite similar to KTWR flood plain [12]. B. arnee uses two types of wallows i.e. mud wallow and bath wallow. The geospatial analysis has shown more suitable water bodies in the western sector because of presence of two big flowing water bodies i.e. Rapti and Reu River in comparison to single flowing Rapti River in the eastern sector.

\section{CONCLUSION}

This habitat suitability analysis of Wild Water Buffalo (Bubalus arnee) in the CNP under the environment of geospatial solutions following the weighted overlay analysis concluded that, in eastern flood plain out of 1943.88 ha. only $1025.85(52.77 \%)$ ha was found highly suitable whereas in western flood plain out of 2422.67 ha only $1593.57(65.77 \%)$ ha was found highly suitable as fitted habitat for wild water buffaloes. The study sites are located in core area away from the human influence and have 
perennial water sources of Rapti River and Reu River. There were plenty of foods available for the wild water buffalo in the both sites; sufficient availability preferred grass species Jhatka (Saccharum arundinacium), Siru (Imperata cylindrical), Kansh (Saccharum spontaenum) and others. Finally, revealed that both study areas possess worth coverage of suitable area which is more than $50 \%$ of total area for wild water buffalo. Comparatively, more suitable area falls under the western sector than eastern sector regarding the analysis of each parameter used in the study. Similarly, western sector floodplain is more suitable based on vegetation analysis, away from the human influence as well as the presence of water bodies. But, the area is far from the central office of the park and very fewer management activities have been done hence; habitat management activity should be done taking wild water buffalo in consideration to make it as the best habitat for wild water buffaloes in the long run.

\section{ACKNOWLEDGEMENT}

We would like to thank DNPWC and CNP for providing permission to conduct this study. We would also like to thanks to Forest Resource Assessment, Nepal (FRA), Babarmahal and NTNC, Sauraha, Chitwan for providing the necessary data and information required for this research. Also extend our thanks to Mr. Jeevan Lamsal, Nripesh Kunwar and Navraj Shahi. We would also like to thanks Ms. Goma Thapa for her continuous encouragement. We would like to thanks for providing the financial support from WWF Nepal, Hariyo Ban program.

\section{REFERENCES}

[1] Aryal, A., Shrestha, T. K., Ram, A., Frey, W., Groves, C., Hemmer, H., Raubenheimer, D. (2011). of Conservation Science, 2(4), 261-268.

[2] Bolton, M. (1975). Royal Chitwan National Park management plan, 1975-1979.

[3] Buxton, R. B. (2013) Cambridge Books Online. Magnetic Resonance Imaging.

[4] Choudury, A. (1994). The decline of water buffalo in north-east India. Oryx, 28, 70-73.

[5] Choudhury, A. U. (2010). The Vanishing herds: The Wild Water Buffalo. Guwahati: Gibbon Books \& The Rhino Foundation for Nature in North-East India.

[6] Dahmer, T. D. (1978). Status and ecology of the wild Asian buffalo ( Bubalus bubalis L .) in Nepal.

[7] Daniel, J. C. \& Grubh, B. R. (1966). The Indian wild buffalo, Bubalus bubalis (L.) in Peninsular India: a preliminary survey. Journal of the Bombay Natural History Society 63(1): 32-53.

[8] Heinen, J. T. (1993). Population viability and management recommendations for wild water buffalo Bubalus bubalis in Kosi Tappu Wildlife Reserve, Nepal. Biological Conservation, 65(1), 29-34. https://doi.org/10.1016/0006-3207(93)90193-5

[9] Heinen, J.T., Srikosamatara, S. (1996). Status and protection of Asian wild cattle and buffalo. Conservation Biology 10 (4), 931-934.

[10] Heinen, J. T., \& Kandel, R. (2006). Threats to a small population: A census and conservation recommendations for wild buffalo Bubalus arnee in Nepal. Oryx, 40(3), 324-330. https://doi.org/10.1017/S0030605306000755

[11] Khadka, B. B., Lamichhane, B.R., \& Aryal, N. (2016) High prey density observed in village evacuated area: A case study from Padampur of Chitwan National Park.

[12] Khatri, T.B., D.N. Shah \& N. Mishra (2012). Wild Water Buffalo Bubalus arnee in Koshi Tappu Wildlife Reserve, Nepal: status, population and conservation importance. Journal of Threatened Taxa 4(14): 32943301.

[13] Lama, R.C. (2004). Status, Distribution and Food Preference of Wild Water Buffalo on Koshi Tappu Wildlife Reserve.

[14] Lehmkuhl, J. F. (2016). National Park, Nepal, 111(1), 29-43.

[15] Nowak, R.M., 1999. Walker's Mammals of the World, 6th Edition. Johns Hopkins University Press, Baltimore, MD

[16] Parihar, J.S., P.C. Kotwal., S. Panigrahi \& N. Chaturvedi. (1986). Study of Wildlife Habitat Using High Resolution Space Photographs: A Case Study of Kanha National Park. ISRO-SP-17-86, Special Publication of Indian Space Research Organisation, Space Applications Centre, Ahmedabad, pp. 65-82.

[17] Ram, A. (2016). Status of Asiatic Wild water buffalo in Nepal, (July). https://doi.org /10.13140/RG.2.1.2 332.31 
[18] Seidensticker, L. (1975). Ungulate populations in Chitwan Valley, Nepal. Office of Zoological Research, National Zoological Park, Smithsonian Institution, Washington, DC (unpublished report).

[19] Timilsina, N., Heinen, J.T. (2008) Forest structure under different management regimes in the western lowlands of Nepal:

[20] Puri, S. (2017). "Host of Parasitic Diseases Detected among wild water buffaloes in CNP". The Kathmandu Post, 3 October. <https://kathmandupost.ekantipur.com/news/2017-10-03/host-of-parasitic-diseasesdetected-among-wild-water-buffaloes-in-cnp.html> Accessed on September 10, 2018

[21] Rimal, T.R. (2017). Tiger Kills Translocated Wild Water Buffalo in CNP”. The Kathmandu Post, 13 December. <https://thehimalayantimes.com/nepal/tiger-kills-translocated-wild-water-buffalo-chitwannational-park/> Accessed on September 13, 2018

[22] BHUJU, U. R., P. R. SHAKYA, T. B. BASNET, and S. SHRESTHA. (2007). Nepal biodiversity resource book: protected areas, Ramsar sites, and World Heritage sites. International Centre for Integrated Mountain Development (ICIMOD), Kathmandu, Nepal.

[23] Ghimire, S.K., M.K. Dhamala, B.R. Lamichhane, R. Ranabhat, K.B. KC \& S. Poudel (2019). Identification of suitable habitat for Swamp Deer Rucervus duvaucelii duvaucelii (Mammalia: Artiodactyla: Cervidae) in Chitwan National Park, Nepal. Journal of Threatened Taxa 11(6): 13644-13653. https://doi.org/10.11609/ jott.4129.11.6.13644-13653

[24] CNP. (2015a). Annual Report 2071/72. Chitwan National Park Office, Kasara, Chitwan, Nepal, 197pp.

Citation: Prabin Poudel, et.al.," Comparative Study in Habitat Suitability Analysis of Wild Water Buffalo (Bubalus arnee) in Two Flood Plains of Chitwan National Park (CNP), Nepal”, International Journal of Research Studies in Zoology, vol. 5, no. 3, p. 1-10, 2019. DOI: http://dx.doi.org/10.20431/2454-941X.0503001

Copyright: (C) 2019 Authors. This is an open-access article distributed under the terms of the Creative Commons Attribution License, which permits unrestricted use, distribution, and reproduction in any medium, provided the original author and source are credited. 